that very few manganese-deficient leaves will respond in this way, the critical level being about 15 p.p.m. manganese on a dry-weight basis. The growth of the manganese-deficient leaves was also less, but they did not develop the characteristic symptoms of this mineral deficiency, even when the level had fallen below that at which symptoms would have appeared on attached leaves. In leaves which had a high or a low manganese content at the time of rooting there was a marked difference in the net assimilation-rate ; but the addition of manganese after rooting to leaves of low content did not increase the assimilation-rate. The effect of manganese content on respiration was found to be slight, though a higher respiration-rate was consistently associated with a higher manganese content. No effect on translocation was detected. The authors point out that the effect of manganese on the assimilation apparatus may occur during the development of the leaf and that once the chloroplast system has become fully developed any manganese deficiency which develops during that phase cannot afterwards be made good. They also indicate, however, that the capacity for chlorophyll formation in deficient leaves is not lost, since considerable greening can be produced by injection, provided the manganese deficiency has not become too advanced.

\section{The National Museums, Ceylon}

THE administration report of the National Museums, Ceylon, for 1953 records the activities at Colombo, Kandy, Ratnapura and Jaffna. It is interesting to note that at the Colombo National Museum an annual attendance of 207,438 included 35,171 sehoolchildren in organized groups. The acquisition of the only known incisor tooth of Rhinoceros sinhaleyus and a series of bone implements, including some notched for attachment to hafts from cave deposits, is reported. On the proposal of the Director, the Colombo Museum Committee decided to conduct a speleological survey of Ceylon to include the zoology and prehistory of all the caves in the Island. Accordingly, a Speleological Association of Ceylon, the membership of which is open to the public, was formed in July 1953.

\section{Swedish National Committee for Physics}

THE seventh general physics conference of the Swedish National Committee for Physics was held at the Chalmers Institute of Technology, Gothenberg, during September 28-30, 1953. The director, Prof. Nils Ryde, gave details of the facilities available at the Institute and described the research work in progress, and Prof. S. Eklöf spoke about the organization of teaching and research in the Electrical Engineering Department. Several distinguished visitors from outside Sweden attended the conference and gøve addresses. These included Dr. M. Edlund (Oak Ridge Laboratories), who gave a survey of recent reactor developments in the United States; Prof. T. W. Bonner (Rice Institute, Houston), who lectured on excited states of light nuclei ; and Dr. A. Bohr and Dr. T. Huus (Copenhagen), who spoke about rotational states of atomic nuclei and the Coulomb excitation of heavier atomic nuclei, respectively. Summaries of the other forty-six papers contributed to the conference are printed in Arkin för Physik, 8, 1; May 1954. They include several contributions from the Atomic Energy Laboratory, Stockholm, and from the Nobel Institute of Physics, Stockholm.

\section{The Nature Conservancy: Awards for 1954}

The Nature Conservancy announces the following awards of research studentships for postgraduate training in ecology, tenable for periods of up to three years at the universities and other institutions named : Botany : A. P. Hughes (Trinity Hall, Cambridge); E. Lodge (University College, London) N. M. Pritchard (Balliol College, Oxford); T. O. Pritchard (Leeds); V. I. Stewart (Aberdeen). Zoology: J. M. Colebrook (Freshwater Biological Association, Far Sawrey, Ambleside) ; J. C. Coulson (Durham); J. B. Ford (Southampton); Miss T. J. White (Imperial College of Science and Technology, London).

\section{Announcements}

THE Council of the Royal Society has appointed Prof. M. L. E. Oliphant, of the Australian National University, as the Rutherford Memorial Lecturer for 1955. Prof. Oliphant will deliver lectures in India and Pakistan.

The 1954 Eddington Lecture is to be given in Cambridge, at the Arts' School Lecture Theatre, Bene't Street, on November 2, at 5 p.m., by Prof. H. Dingle, professor of the history and philosophy of science in University College, London. Prof. Dingle will speak on "The Sources of Eddington's Philosophy".

The War Office announces that Prof. S. J. Davies has been appointed dean of the Royal Military College of Science, Shrivenham. Prof. Davies is professor of mechanical engineering in the University of London at King's College, and will retain his chair until the end of the present academic year.

Dr. E. H. SondHEIMER, lecturer in mathematics in the Imperial College of Science and Technology, London, has been appointed to the University readership in applied mathematics tenable at Queen Mary College, University of London.

Tre Metallurgical Laboratories of the British Welding Research Association are holding open days on November 23 and 24. Admission will be by ticket, obtainable from the Secretary, British Welding Research Association, 29 Park Crescent, London, W.I.

REFERRING to the article on "The Golgi Apparatus" (Nature, July 3, p. 21), Mr. Dennis Lacy writes: "I may inadvertently have given the impression that the views of Dr. J. R. Baker and his colleagues are based solely upon the study of only three different cells (neurones of $L$. migratoria, epithelial cells of the intestine, and Paneth cells). They have indeed published careful accounts which deal specifically with the Golgi problem in nineteen different kinds of cells".

Erratum. In the article on the report for 1953 of the Rothamsted Experimental Station (Nature, September 11, p. 498), referring to the work of the Bee Department, it is said that the fumes produced by adding small quantities of ammonium nitrate to burning smoker fuel provide a simple anæsthetic for use when transferring bee colonies from one site to another a short distance away, since on recovery it is claimed that the bees lose their tendency to drift back to the original site. It should have been added that the Rothamsted work has failed to substantiate this claim, but it is considered that the method, provided that the minimum proportion of ammonium nitrate to fuel is used, is the most efficient and simple one so far suggested for anæsthetizing whole colonies of bees in situ. 